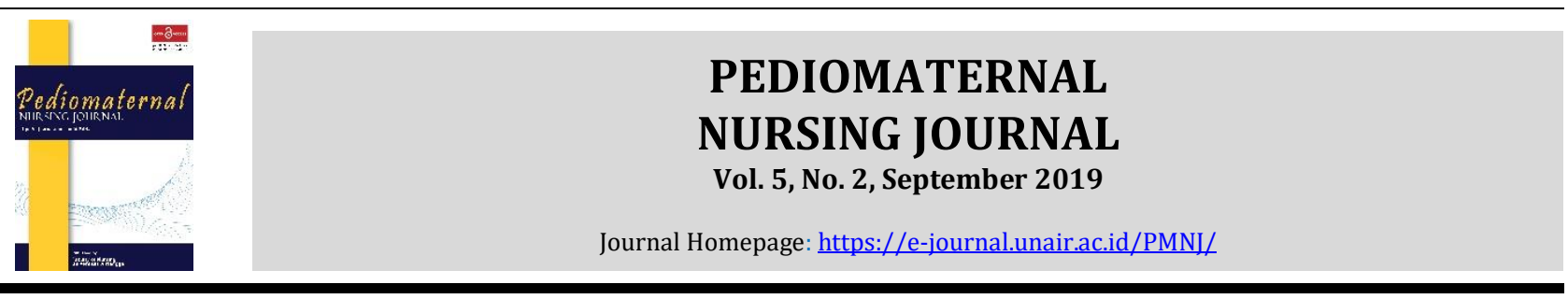

Original Research

\title{
Faktor Risiko Kejadian Ikterus Neonatorum
}

\section{(Risk Factors of Neonatal Jaundice)}

\author{
Nimas Anggie Auliasari ${ }^{1}$, Risa Etika ${ }^{2}$, Ilya Krisnana ${ }^{3}$, dan Pudji Lestari ${ }^{4}$ \\ ${ }^{1}$ Program Studi Kebidanan Fakultas Kedokteran, Universitas Airlangga, Surabaya, Indonesia \\ ${ }^{2}$ Departemen Ilmu kesehatan Anak Fakultas Kedokteran, Universitas Airlangga, Surabaya, Indonesia \\ ${ }^{3}$ Departemen Keperawatan Maternitas dan Anak Fakultas Keperawatan, Universitas Airlangga, Surabaya, Indonesia \\ ${ }^{4}$ Departemen IKM-KP Fakultas Kedokteran, Universitas Airlangga, Surabaya, Indonesia
}

\section{ARTICLE HISTORY \\ Received: May 27, 2019 \\ Accepted: July 23, 2019 \\ KEYWORDS \\ ABO incompatibility; prematurity;LBW; asphyxia; history of mother's DM}

\section{CORRESPONDING AUTHOR}

Nimas Anggie Auliasari nimasanggie04@gmail.com Program Studi Kebidanan, Fakultas Kedokteran, Universitas Airlangga, Surabaya, Indonesia

Cite this as:

\begin{abstract}
Introduction: Neonatal jaundice is a clinical manifestation in neonates characterized by yellow coloration of the skin and sclera due to the accumulation of excess unconjugated bilirubin production in the tissues. Based on the data in the NICU of Dr. Soetomo Hospital, $46.8 \%$ of 844 neonates had neonatal jaundice. Therefore, this study is intended to analyze the risk factors associated with the incidence of neonatal jaundice.

Methods: This study used observational analytic method with case control approach. There are 84 neonates used as samples taken with sequential sampling. The independent variables are $\mathrm{ABO}$ incompatibility, prematurity, Low Birth Weight, asphyxia, and history of Diabetes Mellitus from the mother. Whereas, the dependent variable is neonatal jaundice. The data are in the form of secondary data from neonates and the mothers, analyzed using the Contingency coefficient with $\alpha=0.05$.

Results: $85.7 \%$ of $\mathrm{ABO}$ incompatibility neonates had neonatal jaundice $(\mathrm{p}=0.048, \mathrm{OR}=$ $6.833), 57.4 \%$ of premature neonates had neonatal jaundice $(\mathrm{p}=0.028, \mathrm{OR}=3.077), 42.4 \%$ of LBW neonates had neonatal jaundice ( $\mathrm{p}=0.032, \mathrm{OR}=0.346), 60 \%$ of asphyxia neonates had neonatal jaundice $(\mathrm{p}=0.500), 85.7 \%$ of mother with DM history had neonatal jaundice $(\mathrm{p}=0.048, \mathrm{OR}=6.833)$.

Conclusion: There is a relationship between $\mathrm{ABO}$ incompatibility, prematurity, LBW, history of DM and neonatal jaundice while there is no relationship between asphyxia and the incidence of neonatal jaundice in Dr. Soetomo Hospital.
\end{abstract}

Auliasari, N, A., Etika R., Krisnana, I., \& Lestari, P. (2019). Faktor Risiko Kejadian Ikterus Neonatorum. Pediomaternal Nurs. J., 5(2), 183-188.

\section{PENDAHULUAN}

Upaya dalam meningkatkan kesehatan anak bertujuan untuk mempersiapkan generasi yang berkualitas dan untuk menurunkan angka kematian anak yakni meliputi Angka Kematian Neonatal (AKN), Angka Kematian Bayi (AKB), dan Angka Kematian Balita (AKABA). Berdasarkan hasil Survei Demografi dan Kesehatan Indonesia (SDKI) tahun 2012, AKN sebesar 19 per 1000 kelahiran hidup dan AKB sebesar 22,23 per 1000 kelahiran hidup, yang artinya sudah mencapai target Millenium Development Goals (MDGs) sebesar 23 per kelahiran hidup (1). Akan tetapi, AKB di Indonesia masih tergolong tinggi dibandingkan dengan negara-negara ASEAN seperti, Singapura mencapai 3 per 1000 kelahiran hidup,
Brunei Darussalam mencapai 8 per 1000 kelahiran hidup, dan Malaysia mencapai 10 per 1000 kelahiran hidup (2). Data tersebut menunjukkan bahwa Indonesia perlu melanjutkan program untuk mencapai target Sustainable Development Goals (SDGs) pada tahun 2030 sebesar 12 per kelahiran hidup (3).

Penurunan AKN menjadi perhatian karena kematian neonatal menyumbang 59\% dari kematian bayi (1). Kematian bayi yang utama di Indonesia disebabkan karena BBLR 26\%, ikterus 9\%, hipoglikemia 0,8\% dan infeksi neonatorum 1,8\% (2). Prevalensi kejadian ikterus neonatorum di dunia masih cukup tinggi. Di Amerika Serikat, 65\% dari 4 juta neonatus yang lahir setiap tahunnya mengalami ikterus neonatorum dalam minggu pertama 
kehidupannya. Di Indonesia, menurut data di salah satu Rumah Sakit yaitu di RSUD. Dr. Soetomo menunjukkan peningkatan kejadian ikterus neonatorum, pada tahun 2012 sebanyak 380 kasus, pada tahun 2013 terdapat sebanyak 392 kasus ikterus neonatorum (4), dan pada tahun 2018, terdapat 395 kasus ikterus neonatorum.

Ikterus neonatorum merupakan indikasi klinis pada neonatus yang ditandai dengan pewarnaan kuning pada kulit dan sklera akibat dari akumulasi produksi bilirubin tak terkonjugasi yang berlebih dalam jaringan (5). Ikterus neonatorum disebabkan oleh beberapa faktor diantaranya yaitu inkompatibilitas darah AB0, defisiensi enzim G6PD, keterlambatan pasase mekonium, kurangnya asupan ASI, dan asfiksia (6). Berdasarkan (7), faktor risiko ikterus dibedakan menjadi 3 faktor yaitu, faktor maternal meliputi Ras, komplikasi kehamilan (DM, inkompatibilitas $\mathrm{ABO}$ dan $\mathrm{Rh}$ ), penggunaan infus oksitosin dalam larutan hipotonik, dan ASI. Faktor perinatal meliputi trauma lahir (sefalhematom, ekimosis), dan infeksi (bakteri, virus, protozoa). Faktor neonatal meliputi prematuritas, faktor genetik, polisitemia, obat-obatan, rendahnya asupan ASI, hipoglikemia, dan hipoalbuminemia. Faktor lain yaitu BBLR dan asfiksia. Bayi berat lahir rendah dapat berisiko terjadinya ikterus neonatorum. Beberapa penelitian menunjukan bahwa BBLR lebih mudah mengalami ikterus dibandingkan dengan bayi yang memiliki berat badan lahir normal. Kematangan pada organ bayi BBLR belum maksimal dibandingkan dengan bayi yang memiliki berat badan lahir normal. Proses pengeluaran bilirubin melalui organ hepar yang belum matang menyebabkan terjadinya ikterus pada bayi. Sehingga terjadi penumpukan bilirubin dan menyebabkan warna kuning pada permukaan kulit. Berdasarkan uraian diatas, maka perlu dilakukan penelitian untuk mengetahui faktor risiko kejadian ikterus neonatorum di RSUD Dr. Soetomo.

\section{METODE}

\subsection{Desain}

Penelitian ini adalah penelitian analitik observasional dengan pendekatan case control (retrospektive).

\subsection{Populasi, sampel, dan sampling}

Populasi yang digunakan yaitu seluruh neonatus di ruang NICU RSUD. Dr. Soetomo pada periode Januari - Desember 2018 sejumlah 844 neonatus. Sampel yang digunakan sebanyak 84 neonatus dengan perbandingan 1:1 (42 kasus dan 42 kontrol). Teknik pengambilan sampel menggunakan sequential sampling yaitu pengambilan sampel dengan menggunakan kriteria tertentu yang telah dibuat oleh peneliti sendiri berdasarkan urutan waktu. Adapun kriteria yang ditentukan oleh peniliti yaitu, kriteria inklusi pada sampel kasus adalah neonatus yang memiliki riwayat ikterus neonatorum patologis dengan kadar bilirubin $>5 \mathrm{mg} / \mathrm{dL}$ atau $>13 \mathrm{mg} / \mathrm{dL}$ di hari pertama kehidupan dan memiliki catatan rekam medis yang lengkap. Kriteria inklusi pada sampel kontrol adalah neonatus yang tidak sedang mengalami ikterus patologis atau pernah mengalami ikterus fisiologis dengan kadar bilirubin $>2 \mathrm{mg} / \mathrm{dL}$ di minggu pertama kehidupan dan memiliki catatan rekam medis yang lengkap. Kriteria Eksklusi pada sampel kasus dan kontrol adalah neonatus yang mengalami ikterus neonatorum yang tidak diperiksa golongan darahnya dan nenonatus yang mengalami ikterus neonatorum dikarenakan kelainan kongenital seperti penyakit jantung bawaan, ensefalopati biliaris dan sepsis.

Lokasi penelitian ini yaitu di bagian ruang NICU dan rekam medik RSUD. Dr. Soetomo Surabaya. Waktu pelaksanaan penelitian yaitu antara bulan Agustus 2018 sampai Maret 2019. Pengambilan dan pengumpulan data dilakukan pada bulan Januari 2019 sampai Februari 2019.

\subsection{Variabel}

Variabel independen yaitu inkompatibilitas ABO, prematuritas, BBLR, asfiksia, dan riwayat ibu DM, sedangkan variabel dependen adalah ikterus neonatorum.

\subsection{Instrumen}

Instrumen pada penelitian ini menggunakan data sekunder dari bayi dan ibu pada periode bulan Januari - Desember 2018. Adapun data sekunder yang diambil dari bayi dan ibu yaitu tanggal lahir bayi, apgar score, usia kehamilan, jenis kelamin, riwayat persalinan, berat badan lahir, riwayat asfiksia, riwayat ibu DM dan golongan darah.

\subsection{Prosedur}

Proses pengumpulan data dapat dilakukan setelah mendapatkan surat izin penelitian yang diperoleh dari bagian akademik Program Studi Kebidanan Fakultas Kedokteran Universitas Airlangga dan RSUD Dr. Soetomo Surabaya. Tahapan pengumpulan data diawali dengan penetapan nomor rekam medik neonatus yang mengalami icterus neonatorum beserta ibunya yang sesuai dengan kriteria inklusi dan eksklusi melalui buku register di Ruang NICU RSUD Dr. Soetomo Surabaya. Nomor rekam medik tersebut kemudian digunakan sebagai acuan untuk mendapatkan rekam medik yang diinginkan sebagai sumber data dimasukkan ke dalam lembar pengumpul data.

\subsection{Analisis}

Analisis univariat dilakukan untuk memperoleh gambaran pada masing-masing variabel yang berupa distribusi frekuensi dari masing-masing faktor risiko kejadian ikterus neonatorum. Analisis bivariat menggunakan uji Contingency coefficient untuk mengetahui hubungan antar variabel dengan menggunakan perangkat lunak SPSS dan tingkat kemaknaan $\alpha=0,05$.

\subsection{Ethical Clearance}

Ethical clearance yang digunakan yaitu kelaikan etik yang didapatkan dari tim komite etik penelitian 
kesehatan RSUD Dr. Soetomo dengan nomor sertifikat kelaikan etik yaitu 0905/KEPK/I/2019. Menjaga kerahasiaan pasien dengan baik dengan cara tidak menyebutkan nama tetapi inisial. Data yang diperoleh dan hasil penelitian hanya digunakan untuk kepentingan penelitian saja.

\section{Hasil}

Hasil penelitian didapatkan 42 bayi ikterus dan 42 bayi yang tidak ikterus, sebanyak 77 (91,7\%) tidak mengalami inkompatibilitas ABO, sebanyak 61 $(72,6 \%)$ bayi lahir prematur, sebanyak 59 (70,2\%) bayi lahir dengan berat badan rendah, sebanyak 74 $(88,1 \%)$ bayi tidak mengalami asfiksia, dan sebanyak $77(91,7 \%)$ bayi lahir dari ibu yang tidak memiliki riwayat DM [Tabel 1].

Berdasarkan hasil penelitian, analisis hubungan antara inkompatibilitas ABO dengan kejadian ikterus neonatorum didapatkan sebanyak 6 neonatus $(85,7 \%)$ yang mengalami inkompatibilitas $A B O$ dan hasil uji statistik didapatkan nilai $p$ value $=0,048$ dan OR sebesar 6,833. Hubungan antara prematuritas dengan kejadian ikterus neonatorum didapatkan sebanyak 35 neonatus $(57,4 \%)$ yang lahir prematur dan hasil uji statistik didapatkan nilai $p$ value $=0,028$ dan OR sebesar 3,077. Hubungan antara BBLR dengan kejadian ikterus neonatorum didapatkan sebanyak 25 neonatus $(42,4 \%)$ yang mengalami BBLR dan hasil uji statistik didapatkan nilai $p$ value $=0,032$ dan OR sebesar 0,346. Hubungan antara asfiksia dengan kejadian ikterus neonatorum didapatkan sebanyak 6 (60\%) neonatus yang mengalami asfiksia dan hasil uji statistik didapatkan nilai $p$ value $=0,500$ dan $\mathrm{OR}$ sebesar 1,583. Hubungan antara riwayat ibu DM dengan kejadian ikterus neonatorum didapatkan sebanyak 6 neonatus $(85,7 \%)$ yang lahir dari ibu yang memiliki riwayat DM dan hasil uji statistik didapatkan nilai $p$ value $=0,048$ dan OR sebesar 6,833.

\section{PEMBAHASAN}

Ikterus neonatorum merupakan indikasi klinis pada neonatus yang ditandai dengan pewarnaan kuning pada kulit dan sklera akibat dari akumulasi produksi bilirubin tak terkonjugasi yang berlebih dalam jaringan (5). Bilirubin tak terkonjugasi yang berlebih bersifat racun, tidak mudah larut dalam air dan tidak mudah untuk dibuang. Organ hati berperan untuk menetralisir bilirubin tak terkonjugasi menjadi bilirubin konjugasi agar mudah untuk diserap oleh air. Akan tetapi, fungsi sebagian organ hati pada neonatus belum dapat berfungsi optimal untuk mengeluarkan bilirubin tak terkonjugasi (4). Ikterus dapat berupa fisiologis maupun patologis. Ikterus fisiologis terjadi pada usia $\geq 24$ jam kehidupan dan menghilang $\leq 14$ hari kehidupan dengan kadar bilirubin pada hari kedua sampai keempat yaitu 5 $6 \mathrm{mg} / \mathrm{dL}$ dan menurun menjadi $<2 \mathrm{mg} / \mathrm{dL}$ pada hari kelima sampai ketujuh (8), sedangkan ikterus patologis terjadi pada hari pertama kehidupan $(<24$ jam) atau lebih dari 14 hari kehidupan (9) dengan adanya kadar bilirubin mencapai 5 - 10 mg/dL (10).

4.1 Hubungan Inkompatibilitas ABO dengan kejadian ikterus neonatorum

Hasil penelitian dengan menggunakan uji Contingency coefficient dengan tingkat signifikan $(\alpha=0,05)$ menunjukkan ada hubungan antara inkompatibilitas ABO dengan kejadian ikterus neonatorum di RSUD Dr. Soetomo. Nilai OR yang didapat yaitu 6,833. Artinya neonatus dengan inkompatibilitas $\mathrm{ABO}$ meningkatkan risiko terjadinya ikterus neonatorum 6,833 kali lebih besar dibandingkan dengan neonatus yang tidak inkompatibilitas ABO.

Hasil penelitian ini sejalan dengan penelitian yang dilakukan oleh (11), didapatkan risiko inkompatibilitas ABO 7,188 kali lebih besar

Tabel 1. Analisis Univariat dan Bivariat Ikterus Neonatorum, Inkompatibilitas ABO, Prematuritas, BBLR, Asfiksia, dan Riwayat Ibu DM di RSUD Dr. Soetomo Tahun 2018 (n=84)

\begin{tabular}{|c|c|c|c|c|c|c|c|c|c|c|}
\hline \multirow{3}{*}{ Variabel } & \multicolumn{6}{|c|}{ Kejadian Ikterus } & \multirow{3}{*}{ OR } & \multirow{3}{*}{$\mathbf{p}$} & \multirow{3}{*}{$n$} & \multirow{3}{*}{$(\%)$} \\
\hline & \multicolumn{2}{|c|}{ Kasus } & \multicolumn{2}{|c|}{ Kontrol } & \multicolumn{2}{|c|}{ Total } & & & & \\
\hline & $\mathbf{n}$ & $\%$ & $\mathbf{n}$ & $\%$ & $\mathbf{n}$ & $\%$ & & & & \\
\hline \multicolumn{11}{|l|}{ Inkompatibilitas ABO } \\
\hline Inkompatibilitas $\mathrm{ABO}$ & 6 & 85,7 & 1 & 14,3 & 7 & 100 & \multirow{2}{*}{6,833} & \multirow{2}{*}{0,048} & 7 & 8,3 \\
\hline Tidak inkompatibilitas ABO & 36 & 46,8 & 41 & 53,2 & 77 & 100 & & & 77 & 91,7 \\
\hline \multicolumn{11}{|l|}{ Prematuritas } \\
\hline Prematur & 35 & 57,4 & 26 & 42,6 & 61 & 100 & 3,077 & 0,028 & 61 & 72,6 \\
\hline Aterm & 7 & 30,4 & 16 & 69,6 & 23 & 100 & & & 23 & 27,4 \\
\hline \multicolumn{11}{|l|}{ Bayi Berat Lahir } \\
\hline Bayi berat lahir rendah & 25 & 42,4 & 34 & 57,6 & 59 & 100 & 0,346 & 0,032 & 59 & 70,2 \\
\hline Bayi berat lahir normal & 17 & 68 & 8 & 32 & 25 & 100 & & & 25 & 29,8 \\
\hline \multicolumn{11}{|l|}{ Asfiksia } \\
\hline Asfiksia & 6 & 60 & 4 & 40 & 10 & 100 & 1,583 & 0,500 & 10 & 11,9 \\
\hline Tidak asfiksia & 36 & 48,6 & 38 & 51,4 & 74 & 100 & & & 74 & 88,1 \\
\hline \multicolumn{11}{|l|}{ Riwayat Ibu DM } \\
\hline Ada riwayat DM & 6 & 85,7 & 1 & 14,3 & 7 & 100 & 6,833 & 0,048 & 7 & 8,3 \\
\hline Tidak ada riwayat DM & 36 & 46,8 & 41 & 53,2 & 77 & 100 & & & 77 & 91,7 \\
\hline
\end{tabular}


dibandingkan pada neonatus yang tidak inkompatibilitas ABO. Hal itu juga didapatkan pada penelitian yang dilakukan oleh (12), didapatkan nilai $p=0,004$ yang menunjukkan bahwa ada hubungan inkompatibilitas ABO terhadap kejadian hiperbillirubin pada pasien di Ruang Neonatal RS Semen Gresik.

Inkompatibilitas ABO disebut juga dengan ketidakcocokan antara golongan darah ibu dan bayi. Inkompatibilitas $\mathrm{ABO}$ terjadi pada ibu yang memiliki golongan darah 0 sedangkan bayi memiliki golongan darah A atau B. Ibu yang memiliki golongan darah 0 secara alamiah mempunyai antibodi anti-A dan antiB pada sirkulasinya (13). Jika janin memiliki golongan darah $\mathrm{A}$ atau B, eritroblastosis dapat terjadi yang secara alamiah dapat membentuk anti-A atau anti-B berupa antibodi IgM (Immunoglobulin $M$ ) yang tidak melewati plasenta. Pada sebagian ibu juga relatif mempunyai kadar IgG (Immunoglobulin G) anti-A atau anti-B yang tinggi yang berpotensi sebagai penyebab eritroblastosis karena melewati plasenta. Ibu yang memiliki golongan darah 0 mempunyai kadar IgG anti-A lebih tinggi daripada ibu golongan darah B dan mempunyai kadar IgG anti-B lebih tinggi daripada ibu dengan golongan darah A (14). Golongan darah yang berbeda ini juga dapat menyebabkan hemolisis atau penghancuran sel darah merah pada neonatus yang menyebabkan peningkatan produksi bilirubin. Peningkatan produksi bilirubin ini yang menyebabkan ikterus neonatorum (15).

Menurut peneliti, adanya hubungan antara inkompatibilitas ABO dengan kejadian ikterus neonatorum di RSUD Dr. Soetomo Surabaya disebabkan karena ibu yang memiliki golongan darah $\mathrm{O}$ dan bayi memiliki golongan darah A atau B dapat menyebabkan hemolisis pada neonatus sehingga kadar bilirubin meningkat.

4.2 Hubungan prematuritas dengan kejadian ikterus neonatorum

Hasil penelitian dengan menggunakan uji Contingency coefficient dengan tingkat signifikan $(\alpha=0,05)$ menunjukkan ada hubungan antara prematuritas dengan kejadian ikterus neonatorum di RSUD Dr. Soetomo. Nilai OR yang didapatkan yaitu 3,077 . Artinya neonatus yang lahir dengan usia kehamilan prematur meningkatkan risiko terjadinya ikterus neonatorum 3,077 kali lebih besar dibandingkan dengan neonatus yang lahir dengan usia kehamilan aterm.

Prematuritas berhubungan dengan hiperbilirubinemia tak terkonjugasi pada bayi baru lahir. Hal ini dikarenakan aktivitas uridine diphosphat glukoronil transferase (UDPGT) hepatik yang menurun pada bayi prematur, sehingga bilirubin konjugasi juga menurun. Selain itu juga terjadi peningkatan hemolisis karena umur sel darah merah yang pendek pada bayi prematur yang menyebabkan bilirubin tak terkonjugasi yang banyak dalam darah $(16,17)$.

Hasil penelitian ini sejalan dengan penelitian yang dilakukan oleh Rini (2016), didapatkan risiko prematuritas 1,974 kali lebih besar dibandingkan pada neonatus dengan aterm. Hal itu juga didapatkan pada penelitian yang dilakukan oleh (18), bahwa risiko prematuritas 8,571 kali lebih besar dibandingkan pada neonatus dengan aterm.

Neonataus yang lahir prematur memiliki risiko yang lebih besar untuk terjadi ikterus neonatorum. Hal ini disebabkan hampir seluruh organ tubuh pada neonatus yang prematur masih belum sempurna sehingga enzim pada hepar belum matang dan bilirubin tak terkonjugasi tidak dikonjugasikan secara efektif. Selain itu, bilirubin yang berbahaya adalah bilirubin yang tidak diikat oleh albumin. Neonatus yang lahir prematur memiliki kadar serum bilirubin yang rendah, sehingga kadar bilirubin tak terkonjugasi yang bebas meningkat yang dapat menyebabkan hiperbilirubin dan menimbulkan ikterus neonatorum (18).

\subsection{Hubungan BBLR dengan kejadian ikterus neonatorum}

Hasil penelitian dengan menggunakan uji Contingency coefficient dengan tingkat signifikan $(\alpha=0,05)$ menunjukkan ada hubungan antara BBLR dengan kejadian ikterus neonatorum di RSUD Dr. Soetomo. Nilai OR yang didapatkan yaitu 0,346. Artinya BBL $<2500$ gram meningkatkan risiko terjadinya ikterus neonatorum 0,346 kali lebih besar dibandingkan $\mathrm{BBL} \geq 2500$ gram atau bisa disebut sebagai faktor protektif.

Bayi berat lahir normal maupun bayi berat lahir rendah dapat berisiko terjadinya ikterus neonatorum. Kematangan pada organ bayi BBLR belum maksimal dibandingkan dengan bayi yang memiliki berat badan lahir normal. Proses pengeluaran bilirubin melalui organ hepar yang belum matang menyebabkan terjadinya ikterus pada bayi. Sehingga terjadi penumpukan bilirubin dan menyebabkan warna kuning pada permukaan kulit (19).

Hasil penelitian ini sejalan dengan penelitian yang dilakukan oleh (20), didapatkan risiko BBLR 5,750 kali lebih besar dibandingkan pada neonatus dengan bayi berat lahir normal. Hal itu juga didapatkan pada penelitian yang dilakukan oleh (21), bahwa risiko BBLR yang mengalami ikterus neonatorum sebesar 2,475 kali lebih besar dibandingkan pada neonatus dengan bayi berat lahir normal.

Pada kondisi BBLR, ikterus neonatorum disebabkan karena kematangan organ hepar yang belum maksimal sehingga konjugasi bilirubin tak terkonjugasi menjadi bilirubin terkonjugasi tidak maksimal (6). Proses konjugasi yang tidak maksimal ini dapat menyebabkan proses pengeluaran bilirubin melalui hepar terganggudan dapat menyebabkan penumpukkan bilirubin dan warna kuning pada permukaan kulit (19).

Menurut penelitian yang dilakukan oleh (22), didapatkan risiko BBLR 8,820 kali lebih besar dibandingkan pada neonatus dengan bayi berat lahir normal. Hal ini dikarenakan pada bayi berat lahir 
rendah dapat meningkatkan risiko untuk terjadinya infeksi yang disebabkan oleh menurunnya cadangan imunoglobulin maternal, rusaknya kemampuan untuk membentuk antibodi dan sistem integumen, serta kematangan hepar yang belum maksimal menyebabkan konjugasi bilirubin tak terkonjugasi menjadi bilirubin konjugasi belum sempurna.

\subsection{Hubungan asfiksia dengan kejadian ikterus neonatorum}

Hasil penelitian dengan menggunakan uji Contingency coefficient dengan tingkat signifikan $(\alpha=0,05)$ menunjukkan tidak ada hubungan antara asfiksia dengan kejadian ikterus neonatorum di RSUD Dr. Soetomo.

Hasil penelitian ini tidak sesuai dengan penelitian yang dilakukan oleh Widiawati (2017), didapatkan bahwa neonatus dengan asfiksia memiliki risiko 4,900 kali lebih besar dibandingkan pada neonatus tidak asfiksia. Hal tersebut juga didukung dengan penelitian yang dilakukan oleh (23), didapatkan bahwa neonatus dengan asfiksia memiliki risiko 2,181 kali lebih besar dibandingkan pada neonatus tidak asfiksia. Sebaliknya, penelitian yang dilakukan oleh (24), menunjukkan bahwa tidak ada hubungan antara asfiksia dengan kejadian ikterus neonatorum $(p=0,492)$.

Keadaan asfiksia dapat menyebabkan hipoperfusi hati yang akan mengganggu uptake dan metabolisme bilirubin hepatosit, serta produksi bilirubin tak terkonjugasi yang meningkat melebihi kemampuan untuk mengeluarkannya. Hal ini yang dapat menyebabkan ikterus neonatorum (16). Selain itu, ikterus neonatorum yang disebabkan oleh asfiksia dikarenakan pada masa neonatus ini fungsi organ hepar belum maksimal sehingga proses glukoronidasi bilirubin tidak terjadi secara maksimal atau jika terdapat gangguan dalam fungsi hepar akibat hipoksia, asidosis atau kekurangan glukosa sehingga dapat menyebabkan kadar bilirubin tak terkonjugasi dalam darah meningkat (23).

Menurut peneliti, penyebab tidak signifikannya hasil analisis penelitian ini dapat disebabkan oleh beberapa faktor. Faktor-faktor tersebut dapat berupa adanya variabel perancu yang tidak diprediksi oleh peneliti atau akibat masalah persebaran data dan faktor-faktor lain yang memisahkan banyak hal jika dilakukan pengkajian lebih lanjut. Menurut (24), asfiksia bukan merupakan faktor utama yang dapat mengakibatkan ikterus. Akan tetapi, ada masalah lain yang timbul pada neonatus yang memiliki riwayat asfiksia yaitu tidak adekuatnya asupan nutrisi berupa ASI dikarenakan harus dilakukan resusitasi segera setelah lahir tanpa IMD. Asupan nutrisi yang kurang akan menyebabkan dehidrasi pada neonatus. Hal ini dapat meningkatkan risiko ikterus neonatorum karena fungsi hati neonatus terganggu akibat hipoperfusi dan kurangnya asupan ASI yang masuk ke usus dapat menurunkan rangsangan defekasi untuk ekskresi bilirubin. Apabila ekskresi bilirubin terganggu akan terjadi penumpukan bilirubin yang menyebabkan warna kuning pada permukaan kulit.
4.5 Hubungan riwayat Ibu DM dengan kejadian ikterus neonatorum

Hasil penelitian dengan menggunakan uji Contingency coefficient dengan tingkat signifikan $(\alpha=0,05)$ menunjukkan ada hubungan antara riwayat ibu DM dengan kejadian ikterus neonatorum di RSUD Dr. Soetomo. Nilai OR yang didapatkan yaitu 6,833. Artinya neonatus yang lahir dari ibu yang memiliki riwayat DM meningkatkan risiko terjadinya ikterus neonatorum 6,833 kali lebih besar dibandingkan neonatus yang lahir dari ibu yang tidak memiliki riwayat DM.

Hasil penelitian ini sejalan dengan penelitian yang dilakukan oleh (25), didapatkan bahwa neonatus dengan riwayat Ibu DM memiliki risiko 2,5 kali lebih besar dibandingkan pada neonatus tidak ada riwayat Ibu DM.

Pada neonatus yang dilahirkan dari ibu yang memiliki riwayat DM akan meningkatkan risiko terjadinya hiperbilirubin. Hal ini dikarenakan proses konjugasi yang tidak efektif karena enzim glucuroniltransferase belum sempurna sehingga kadar bilirubin tak terkonjugasi meningkat. Tidak hanya itu, neonatus yang dilahirkan dari Ibu yang memiliki riwayat DM memiliki sumber bilirubin lain yang berasal dari proses eritropoesis yang belum efektif. Prekursor sel darah merah yang beredar di pembuluh darah terjebak di lien dan dihancurkan. Pemecahan sel darah merah ini memberikan kontribusi terhadap beban bilirubin tambahan ke hati. Sistem proses bilirubin yang tidak efektif pada neonatus yang lahir dari ibu yang memiliki riwayat DM ini menghasilkan kenaikan yang lebih cepat dari konsentrasi puncak serum bilirubin pada bayi (25).

Menurut peneliti, adanya hubungan antara riwayat ibu DM dengan ikterus neonatorum di RSUD Dr. Soetomo Surabaya disebabkan karena neonatus dari ibu DM lahir pada usia kehamilan kurang bulan sehingga memiliki risiko lebih tinggi untuk terjadinya hiperbilirubinemia. Hal ini dikarenakan lamanya neonatus didalam kandungan akan menyebabkan hiperglikemia kronis yang berpengaruh pada janin dan diikuti hiperinsulinemia. Pada kondisi ini terjadi hemolisis yang berlebih, proses eritropoesis yang tidak efektif dan kemampuan hepar yang belum matang untuk mengonjugasi dan mengeksresi bilirubin.

\section{KESIMPULAN}

Faktor resiko terjadinya ikterus neonatorum yaitu hampir seluruh neonatus tidak mengalami inkompatibilitas ABO, sebagian besar neonatus lahir prematur, sebagian besar neonatus lahir dengan berat badan rendah, hampir seluruh neonatus tidak mengalami asfiksia, dan hampir seluruh neonatus lahir dari ibu yang tidak memiliki riwayat DM. Disarankan agar masyarakat dapat melakukan deteksi dini dan melakukan pemeriksaan ANC terpadu secara komprehensif untuk mencegah terjadinya prematuritas, BBLR dan riwayat ibu DM yang merupakan faktor risiko terjadinya ikterus 
neonatorum. Bagi tenaga kesehatan dapat memberikan penyuluhan secara rutin kepada pasien yang berkunjung mengenai faktor risiko terjadinya ikterus neonatorum dan pencegahannya selama kehamilan. Bagi peneliti selanjutnya perlu dilakukan penelitian terkait faktor-faktor risiko yang lebih spesifik untuk mengetahui dengan jelas gambaran penyebab kejadian ikterus neonatorum dan perlu dilakukan penelitian dengan menggunakan desain penelitian yang lebih baik dan memperbanyak jumlah sampel penelitian.

\section{UCAPAN TERIMA KASIH}

Peneliti mengucapkan terima kasih kepada seluruh responden, pihak RS, serta semua pihak yang telah membantu selama proses penelitian berlangsung.

\section{DAFTAR PUSTAKA}

1. Kemenkes R. Profil Kesehatan Indonesia Tahun 2016 (Ketua: Budijanto). Jakarta: Kementerian Kesehatan RI; 2017.

2. Marlina L, Fitrihadi E. Gambaran karakteristik ibu dengan kejadian ikterus pada neonatus di rsud wates kulon progo. 2017;

3. Organization WH. Health in 2015: from MDGs, Millennium Development Goals to SDGs, Sustainable Development Goals. Geneva: World Health Organization; 2015.

4. Rini K. analisis faktor risiko yang berhubungan dengan ikterus neonatorum fisiologi di ruang cendrawasih RSUD Dr Soetomo th 2013. 2016;

5. Ali et al. Icterus Neonatorum in Near-Term and Term Infants. 2012;

6. Sukadi A. Hiperbilirubinemia. Dalam: Kosim MS, Yunanto A, Dewi R, Sarosa GI, Usman A. Buku Ajar Neonatologi. Edisi 1 Cetakan kedua. Jakarta: IDAI; 2010.

7. Moeslichan et al. Tata Laksana Ikterus Neonaturum di Indonesia. Jakarta: HTA Indonesia; 2004.

8. Widagdo. Tatalaksana Masalah Penyakit Anak Dengan Ikterus. Jakarta: CV Sagung Seto; 2012.

9. Kemenkes R. Buku Saku: Pelayanan Kesehatan Neonatal Esensial. Jakarta; 2010.

10. Marcdante K, Kliegman R, Jenson H, Behrman R. Nelson Ilmu Kesehatan Anak Esensial. Singapore: Saunders Elsevier; 2014.

11. Anggraini H. Faktor-Faktor yang Berhubungan Dengan Kejadian Ikterus Pada Neonatal. 2017;

12. Fatmawati L, Sumiati. Analisis Faktor - Faktor Yang Berhubungan Dengan Kejadian Hiperbillirubin. Journals Ners Community.
2017;8(1):11-9.

13. Nartono K. Inflamasi plasenta sebagai faktor ikterogenik neonatal pada inkompatibilitas golongan darah ABO ibu-janin. Jakarta: Universitas Indonesia; 2013.

14. Ozcan M, Sevinç S, Erkan V. Hyperbilirubinemia Due To Minor Blood Group Incompatibility In New Born: A Case Report. Turkish Pediatr Assoc. 2017;

15. Maryanti. Buku ajar neonatus dan bayi. Jakarta: Trans Info Media; 2011.

16. Martiza L, Juffrie M, Oswari H, Arief S, Rosalina I. Buku ajar gastroenterologi-hepatologi. Jakarta: Badan Penerbit IDAI; 2012. 263-284 p.

17. Aina $Y$, Omoigberale A. Risk factors for neonatal jaundice in babies presenting at the university of benin teaching hospital, benin city. Niger J Paed. 2012;39(4):159-63.

18. Susilowati L. Faktor-Faktor Yang Berhubungan Dengan Terjadinya Hiperbilirubin Pada Neonatus Di Rsb Permata Hati. J Nifas. 2017;2(2):42-53.

19. Yaestin N. Hubungan Berat Badan Lahir Rendah Dengan Kejadian Ikterus Di RS PKU Muhammadiyah Yogyakarta. Aisyiyah Yogyakarta; 2017.

20. Madiastuti M, Chalada S. Faktor - Faktor Yang Berhubungan Dengan Kejadian Neonatus Hiperbilirubin Di Rsb Pasutri Bogor Provinsi Jawa Barat Tahun 2016. Ilmu Dan Budaya. 2016;40(55):6385-404.

21. Latifah L, Nirmala S, Astuti S. Hubungan antara bayi berat lahir rendah dengan kejadian Ikterus Di Rumah Sakit Umum Daerah Soreang Periode Januari-Desember Tahun 2015. Midwife J. 2017;3(2):13-21.

22. Widiawati S. Hubungan sepsis neonatorum, BBLR dan asfiksia dengan kejadian ikterus pada bayi baru lahir. Ris Inf Kesehat. 2017;6(1).

23. Rohani S, Wahyuni R. Faktor-Faktor yang Berhubungan Dengan Kejadian Ikterus Pada Neonatus. J Ilmu Kesehat. 2017;2(1):75-80.

24. Sursilah I, Hidayah F, Ardiyanti T. Faktor-Faktor Yang Berhubungan Dengan Kejadian Ikterus Pada Bayi Di Ruang Perinatologi Rsud 45 Kuningan Januari S.D. Desember Tahun 2015. 2015;

25. Biade D, Wibowo T, Wandita S, Haksari EL, Julia M. Faktor Risiko Hiperbilirubinemia pada Bayi Lahir dari Ibu Diabetes Melitus. Sari Pediatr. 2018;18(1):6. 